\title{
Environmental Geochemistry of Soils and Stream Sediments from the Birnin-Gwari Artisanal Gold Mining Area, North-western Nigeria
}

\author{
Nuhu Musa Waziri \\ Department of Geology, Federal University of Technology, Minna, PMB 65, Minna, Nigeria \\ *Corresponding Author: nuhuwaziri@futminna.edu.ng
}

Copyright (C) 2014 Horizon Research Publishing All rights reserved.

\begin{abstract}
The geochemistry of surface soils and stream sediments from the Birnin-Gwari area in the north-western Nigeria Schist Belt was studied in order to assess the environmental impact of small-scale artisanal mining of quartz-gold-sulfide mineralization. Total elemental concentration was measured using X-ray fluorescence spectrometry. The results show elevated concentrations of silica, zirconium and paucity of base cations due to intense tropical weathering, accompanied by removal of fine labile fractions by wet season flooding and dry directional winds. This has implication for water chemistry in the area, especially with respect to $\mathrm{pH}$ due to low buffering capacity. The results further show that artisanal mining has not caused severe potentially toxic elements contamination. The consistently higher arsenic concentrations, relative to baseline values, were found not to vary between the mine-impacted and background areas. It is therefore interpreted to have been contributed by the use of agrochemicals in the area. The study has not found a significant human health risk associated with potentially toxic element uptake from mine wastes. It is however recommended that the distribution of arsenic in the soils, sediments and surface water in the area should be further studied in order to ascertain the sources and possible human health implications.
\end{abstract}

Keywords Extractive Industry, Trace Elements, Pollution, Human Health

\section{Introduction}

The environmental and health implications of mining have long been studied and scientific literature [e.g. 1, 2, 3, 4, 5] is full of documented cases of damage to the environment and human health directly linked to mining related pollution. Environmental problems related to artisanal gold mining are widely reported in the developing world, for example, Ghana
[6, 7]; Ecuador [8] and the Brazilian Amazon [9]. Elevated levels of PTEs may be found in and around the mines due to the dispersion of mine wastes down slope by surface runoff, wind action and effluent drainage into nearby soils and open water systems [10]. In the Tsofon Birnin-Gwari region and many other parts of Nigeria, exploitation of gold and associated sulfide minerals by artisans is a common practice and may introduce associated potentially toxic elements (PTEs) into the soils and stream sediments in the area. The area has a relatively long history of gold mining, which peaked in the $1930 \mathrm{~s}$. While large scale production is no longer practiced, small-scale outfits have continued to flourish in the area, involving artisans using crude methods. These non-formal operations are hardly regulated by government agencies, thus, their impact on the environment may go completely unnoticed. Sediment transport is an important means through which contaminants are moved mostly in clastic form, but also hydromorphically from source to areas where their ecological and human health risks are felt. Erosion and transport of contaminated soils ensure that contaminants are taken to areas far away from their source environment. Soils and sediments serve as both sources and sinks of potentially toxic elements. Contaminant species introduced into the soil and sediment environment may be immobilized by sorption and complexation with, for example Iron and Manganese oxides and organic/humic substances. This is however dependent on a number of geochemical conditions such as $\mathrm{pH}$ and the prevailing redox conditions. Under right $\mathrm{pH}$ and redox situations and the right pathways, these elements can easily be mobilized and transmitted through for example, water and the food chain to humans. Not much attention has been paid to the possible implications of artisanal gold and base metal mining in the area and the effect it will have on the quality of the environment and human health. It is often viewed by many as a small-scale industry; incapable of posing any significant environmental and human health risks. The aim of this work is therefore to assess the impact of small-scale artisanal mining of gold in the Birnin-Gwari area, with respect to soil 
and sediment contamination and the possible human health risks. The study discusses the concentration of major and trace elements in soils and sediments in the area in relation to artisanal mining with a view to identifying sources and possible environmental and health risks. The result is expected to show the extent to which artisanal mining of gold-quartz reef deposits has impacted the environment.

\section{Methodology}

\subsection{Study Area and Sampling Method}

The study area is located in Birnin-Gwari local government area of Kaduna state in north-western Nigeria. It lies between latitude $10^{\circ} 55^{\prime} \mathrm{N}$ and $11^{\circ} 05^{\prime} \mathrm{N}$ and longitude $6^{\circ} 45^{\prime} \mathrm{E}$ and $6^{\circ} 52^{\prime} \mathrm{E}$ (Figure 1). The altitude of the area ranges from $518.16 \mathrm{~m}$ to $712.28 \mathrm{~m}$ above mean sea level and is traversed by the Birnin-Gwari/ Funtua road. It is characterized by granitic inselbergs and roughly north-south trending ridges, often in conformity with the general trend in the Nigerian Basement Complex. It is drained mainly by the Kureta and Gora Rivers which are fed by a number of other tributary channels such as the Baigado and Abuya Rivers [11].

The area lies within the Kushaka Schist Belt and is characterized by a number of curved schist belts. It is underlain mainly by semi-pelitic biotite muscovite schist, along with phyllites, metasiltstones and graphitic schists [12]. These units are interbedded with a banded iron formation and the thick amphibolites in parts of the area have been interpreted by Turner as indication of large volcanic accumulation. Truswell and Cope [13] have described the rocks in the area as lying in a number of N-S trending isoclinal fold structures; pelitic metasediments been the dominant lithology, with the presence however of psammites, pelites and amphibolites. The metasediments in this area have been extensively invaded by granites and granodiorites of the Pan-African series and the belt has been placed by Turner [12] in the Kibaran $(1100 \pm 200 \mathrm{Ma})$. The granites were observed to form very prominent geomorphological features especially in the southern part of the study area, while to the north-west, the older migmatite-gneiss basement outcrops. According to Garba [14] the entire sequence in this area has been cut and displaced by the NE-SW trending Kalangai transcurrent fault. The area is associated with extensive mineralization and Woakes and Bafor [15] have named it as one of the areas associated with gold mineralization within the Nigerian Schist Belts. The Tsofon Birnin-Gwari gold-sulphide-quartz reef system has a strike length of over $7 \mathrm{~km}$ and the mineralization is hosted by graphitic and micaceous phyllites [16]. The gold deposit has over the years been exploited by small-scale mining outfits and in the 1930s was reported to have yielded over 600 ounces (over $17 \mathrm{~kg}$ ) of reef and alluvial gold [17]. This, and the neighbouring Kwaga site are still been exploited by artisanal miners. Gold in this area is generally associated with pyrite and minor sphalerite, chalcopyrite, pyrrhotite, galena and magnetite [18], with quartz, potassic feldspar and carbonaceous matter constituting the gangue minerals.

A total of fifty six (56) samples of top soils, stream bed sediments and termite mounds were collected from the study area. The samples were randomly collected from topographic lows and flood plains of streams draining the mine sites and from background areas. At each sampling point, three samples were collected from the top $5 \mathrm{~cm}$ at the apices of a roughly equilateral triangle with sides one meter long. These were subsequently mixed up to make a composite sample and placed in self-sealing polythene bags until analysis.

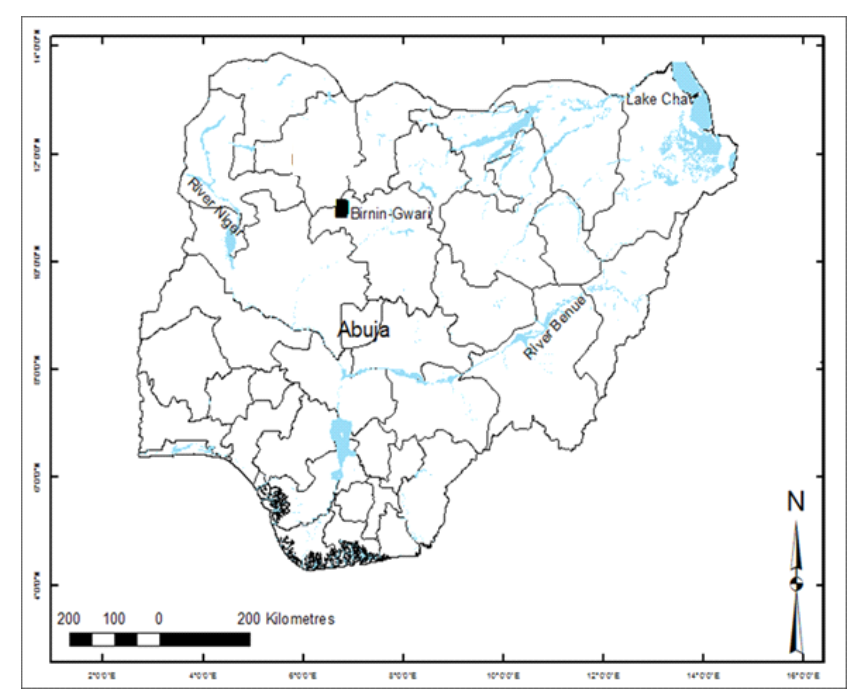

Figure 1. Location of the study area in north-western Nigeria [modified from 19].

\subsection{X-ray Fluorescence Spectrometry Analysis of Soils and Sediments}

The total or near total concentration of trace elements and major oxides in soils and sediments was measured by X-ray fluorescence (XRF) spectrometry. In order to determine total trace element concentration, $7.5 \mathrm{~g}$ of the sieved, oven-dried sample was mixed with three (3) cellulose tablets and the mixture was pulverized in an agate mill (Retsch RS 200) for 1 minute. This was followed by pressing the powder into 25 $\mathrm{mm}$ pellets using a hydraulic press at a pressure of 20 tons. The cellulose serves dual purposes as a binder and also reduces absorption of the target material [20,21]. Glass beads were prepared by mixing approximately $7.60 \mathrm{~g}$ Lithium borate flux with $0.40 \mathrm{~g}$ of the sample in a platinum crucible. The mixture was then fused on an air-acetylene flame $\left(800\right.$ to $1200^{\circ} \mathrm{C}$ ) for fifteen (15) minutes so that the flux melts and the sample dissolves [22]; the melt was allowed to cool into a one-phase glass bead.

Analysis was carried out using a high performance sequential wavelength dispersive XRF spectrometer (S4 
PIONEER) from Bruker AXS, Germany with SPECTRA ${ }^{\text {plus }}$ XRF software. The set-up consists of a $75 \mu \mathrm{m}$ ultra-thin $\mathrm{x}$-ray tube source and a LiF 220 high resolution analyzer crystal detector applicable for Ti or $\mathrm{V} \mathrm{K} \alpha$ to Mo $\mathrm{K} \alpha$ which gives higher resolution and reduces spectrum overlap interferences. The quantification limits (LOQ) for the trace elements measured in this work are $10 \mu \mathrm{g} / \mathrm{g}$ for $\mathrm{As}, \mathrm{Sc}, \mathrm{Cr}, \mathrm{V}, \mathrm{Ni}, \mathrm{Cu}$, $\mathrm{Nb}, \mathrm{Mo}, \mathrm{Sr}, \mathrm{Rb}$, Th, U, Y, La and Ce; $9 \mu \mathrm{g} / \mathrm{g} \mathrm{Zn} ; 5 \mu \mathrm{g} / \mathrm{g} \mathrm{Pb}$; $24 \mu \mathrm{g} / \mathrm{g} \mathrm{Ba}$ and $6 \mu \mathrm{g} / \mathrm{g} Z \mathrm{r}$. In order to allow for data analysis, concentrations below LOQ were replaced with half the LOQ for some of the trace elements [23, 24, 25]. While those data points may not be very reliable, this is probably a better alternative to assigning zero concentration or removing the affected samples from the database.

In order to check analytical accuracy, four certified reference materials (CRMs) were always included among each batch of samples $(\mathrm{n}=10)$. These are SDO-1, W2a, MESS-2 and STSD-2 for the trace elements and major elements. The measured results of most of the elements show very good agreement with the certified values, thus showing good measurement accuracy.

The loss-on-ignition (LOI) which is a proxy for organic matter content of the sample was measured by ignited the sample in a furnace overnight at $300^{\circ} \mathrm{C}$ and determining the difference in weight.

\section{Results and Discussion}

\subsection{Major Element Geochemistry}

Table 1 is the summary statistics of the concentrations of major and trace elements and organic matter contents for the soil and sediment samples from the Birnin-Gwari area of NW Nigeria. The table presents the results of this work, along with the crustal averages $[26,27,28,29]$ and soil guideline values for some of the potentially toxic elements (ICRCL; USEPA) and the concentration of the elements in stream sediments from a similar terrane in central Nigeria [30].

The results (Table 1) for $\mathrm{SiO}_{2}, \mathrm{TiO} 2, \mathrm{Al}_{2} \mathrm{O}_{3}$ and $\mathrm{Fe}_{2} \mathrm{O}_{3}$ are $78.4 \pm 8$ wt. $\%, 1.2 \pm 0.4$ wt. $\%, 9.2 \pm 4$ wt. $\%$ and $4.6 \pm 3$ wt. $\%$ respectively. The results further show that the mean concentrations of $\mathrm{MgO}, \mathrm{CaO}, \mathrm{K}_{2} \mathrm{O}, \mathrm{Na}_{2} \mathrm{O}, \mathrm{MnO}$ and $\mathrm{LOI}$ are low compared to their crustal averages. A major feature of these results is the elevated silica contents and depletion in alumina and the alkalis relative to their published crustal average values [26, 27, 28, 29]. Similarly, the soils of this area have generally low organic matter content as indicated by the low mean percentage loss on ignition, LOI \%. Iron content is however similar to the global average values.

The high silica contents, coupled with depletion in alumina and the alkalis, relative to the upper continental crust, is a reflection of the preponderance of quartz relative to feldspar, mafic, carbonate and clay minerals in the soils and sediments from the two areas. The very high silica concentration in soils and sediments is similar to those obtained by Tijani et al. [31] for bedrock and soils overlying granite-gneiss and pegmatite (60.3-72.2 \%) and schist-quartzite (81-91.3 \%) in SW Nigeria. They are also similar (except for $\mathrm{SiO}_{2}$ ) to those reported for stream sediments in central Nigeria (Table 1) [30], where the depletion in aluminum and the alkalis in the sediments relative to the upper continental crust, was attributed to the maturity of the chemical weathering process, which involves the progressive loss of the alkalis accompanied by an enrichment of sesquioxides [31]. Many previous workers [e.g. 32, 31] have used the chemical index of alteration, CIA [33] as a measure of the degree of weathering and is calculated according to the equation:

$$
C I A=\frac{\mathrm{Al} 203}{A l 203+\mathrm{CaO}+\mathrm{Na} 2 \mathrm{O}+\mathrm{K} 2 \mathrm{O}} \times 100
$$

The computed CIA values for the Birnin-Gwari area lie between 69.1 and 88.3 , with a mean of 79 . These generally indicate that the soils and sediments from the area have undergone intense weathering and removal of alkali metals from feldspars by aggressive soil solutions [33]. It may also be a result of considerable leaching of bases in the upper horizons of the soils as evidenced by low base saturation and low $\mathrm{pH}$ values [34], which leaves the soils enriched in silica. Whether the $\mathrm{pH}$ of soil solutions in the area is sufficiently low to cause the leaching of base cations faster than they are re-supplied by weathering $[35,36]$ is not clear. Three termite mound soils analyzed show high alumina concentrations $(\sim$ 11 - 16.5 wt. \%) compared to most of the surface soil samples, but their alkali contents do not differ significantly from those of the surface soils and stream sediments. A possible reason for this is the origin of the termataria samples from deeper soil environments that have not undergone leaching relative to the top soils. Termites are known to actively transport materials rich in clay minerals from deeper regolith to the surface horizons [37].

The low organic matter content of the soils is consistent with the findings of Pullan [34]. This is perhaps due to the sparse vegetation cover of the area, which is further exacerbated by intensive slash and burn agricultural practices and overgrazing by cattle. According to Andrews et al. [26], soil organic matter is mainly contributed by vegetation, although they note that most soils contain less than $5 \mathrm{wt}$ \% organic matter. The destroyed organic material may have also facilitated the removal of elements such as K, $\mathrm{Ca}, \mathrm{Mg}$ and $\mathrm{Na}$ through leaching and overland runoff, thus, helping to explain their depletion in these soils. The paucity of exchangeable metals in these soils may be the reason for the low partitioning of heavy metals with the exchangeable fraction obtained by Waziri [19]. This might also have implications for water chemistry in the catchment; water $\mathrm{pH}$ may be lowered due to low buffering capacity of the surface soils and sediments. 
Table 1. Summary of XRF data for major (wt. \%) and trace elements ( $\mu \mathrm{gg}-1$ ) in soils and sediments from Birnin-Gwari area, NW Nigeria, along with published concentrations and soil guideline values for some potentially toxic elements.

\begin{tabular}{|c|c|c|c|c|c|c|c|c|c|c|c|}
\hline \multirow[t]{2}{*}{ Element } & \multicolumn{5}{|c|}{ This work } & \multicolumn{3}{|c|}{ Cont. Crust } & \multicolumn{2}{|c|}{ Soils } & \multirow{2}{*}{$\frac{\text { Sediment }}{\mathrm{f}^{*}}$} \\
\hline & Min & Max & Mean & Med & Std. Dev. & $\mathrm{a}$ & $b^{*}$ & $\mathrm{c}$ & $\mathrm{d}$ & $\mathrm{e}$ & \\
\hline $\mathrm{SiO}_{2}$ & 64.6 & 92.2 & 78.4 & 79.4 & 8 & 65 & 66 & 62 & & & 59.5 \\
\hline $\mathrm{TiO}_{2}$ & 0.2 & 2.0 & 1.2 & 1.2 & 0.4 & 0.6 & 0.5 & 0.7 & & & 1.7 \\
\hline $\mathrm{Al}_{2} \mathrm{O}_{3}$ & 4.0 & 17.6 & 9.2 & 8.1 & 4 & 15 & 15 & 15 & & & 10.9 \\
\hline $\mathrm{MnO}$ & 0.01 & 0.7 & 0.1 & 0.08 & 0.1 & & 0.1 & 0.1 & & & 0.1 \\
\hline $\mathrm{MgO}$ & 0.1 & 0.9 & 0.3 & 0.2 & 0.2 & 2.4 & 2.2 & 3.7 & & & 0.5 \\
\hline $\mathrm{Fe}_{2} \mathrm{O}_{3}$ & 0.8 & 12.1 & 4.6 & 3.4 & 3 & 4.9 & 5 & 6.3 & & & 4.5 \\
\hline $\mathrm{CaO}$ & 0.03 & 0.6 & 0.2 & 0.2 & 0.1 & 4.1 & 4.2 & 5.5 & & & 1.2 \\
\hline $\mathrm{P}_{2} \mathrm{O}_{5}$ & 0.01 & 0.1 & 0.05 & 0.04 & 0.02 & & 0.2 & 0.2 & & & 0.04 \\
\hline $\mathrm{K}_{2} \mathrm{O}$ & 0.9 & 3.4 & 1.8 & 1.76 & 0.5 & 3.1 & 3.4 & 2.4 & & & 2.3 \\
\hline $\mathrm{Na}_{2} \mathrm{O}$ & 0.1 & 0.5 & 0.2 & 0.2 & 0.1 & 3.5 & 3.9 & 3.2 & & & - \\
\hline LOI & 1.3 & 9.3 & 5 & 4.4 & 2 & & & & & & - \\
\hline $\mathrm{Sc}$ & 10 & 18 & 11 & 10 & 2 & & 11 & 16 & & & - \\
\hline $\mathrm{V}$ & 24 & 127 & 58 & 56 & 20 & & 60 & 98 & & & 80.4 \\
\hline $\mathrm{Cr}$ & 28 & 100 & 51 & 48 & 15 & & 35 & 126 & 54 & 68 & 56.4 \\
\hline $\mathrm{Ni}$ & 10 & 30 & 16 & 15 & 6 & & 20 & 56 & 19 & 22 & 16.9 \\
\hline $\mathrm{Cu}$ & 10 & 40 & 11 & 10 & 5 & & 25 & 25 & 25 & 22 & 16.5 \\
\hline $\mathrm{Zn}$ & 15 & 77 & 30 & 27.5 & 12 & & 71 & 65 & 60 & 66 & 41 \\
\hline As & 10 & 94 & 24 & 19 & 14 & & 1.5 & & 10 & - & 1.62 \\
\hline $\mathrm{Rb}$ & 31 & 148 & 74 & 67 & 28 & & 112 & 78 & & & 76.7 \\
\hline $\mathrm{Sr}$ & 23 & 127 & 56 & 52 & 19 & & 350 & 333 & & & 201 \\
\hline $\mathrm{Zr}$ & 251 & 4656 & 1597 & 1321 & 1207 & & 190 & 203 & & & 2100 \\
\hline $\mathrm{Nb}$ & 10 & 38 & 23 & 23 & 6 & & 25 & 19 & & & 29.1 \\
\hline Mo & 10 & 10 & 10 & 10 & 0 & & 1.5 & & & & 0.73 \\
\hline $\mathrm{Ba}$ & 162 & 849 & 467 & 447.5 & 146 & & 550 & 584 & & & 808 \\
\hline $\mathrm{La}$ & 20 & 67 & 39 & 37 & 12 & & 30 & 30 & & & 99.9 \\
\hline $\mathrm{Ce}$ & 40 & 115 & 77 & 76.5 & 16 & & 64 & 60 & & & 211 \\
\hline $\mathrm{Pb}$ & 20 & 53 & 28 & 28 & 5 & & 20 & 15 & 19 & 30 & 28 \\
\hline Th & 10 & 45 & 21 & 19 & 8 & & 11 & 8.5 & & & 40.8 \\
\hline $\mathrm{U}$ & 10 & 10 & 10 & 10 & 0 & & 2.8 & 1.7 & & & 8.09 \\
\hline
\end{tabular}

a: Andrews et al26; b: Upper continental crust, Taylor and McLennan27,28 c: Wedepohl29; d:ICRCL/DEFRA Trigger concentrations for domestic gardens/allotments ; e:US EPA soil guideline values; f: stream sediments from central Nigeria [30]. *Major elements oxides worked out from elemental concentrations.

\subsection{Trace Element Geochemistry}

The results of potentially toxic element analysis are summarized in Table 1, along with published concentrations and trigger and / or guideline soil concentrations for As and five heavy metals. The results show that only $\mathrm{Pb}$ and As have mean concentrations above the published crustal abundances (Table 1), whereas the concentration of $\mathrm{Cr}$ exceeded only the Taylor and McLennan [28] value of $35 \mu \mathrm{g} / \mathrm{g}$. The results were also compared with the trigger and guideline value for potentially toxic elements in soils and this shows that the mean concentration of As is above the limit set for domestic gardens and allotments. The mining of gold is an important source of As in the environment $[38,39]$, but the results of this work do not show a significant elevation of As concentration in areas severely affected by artisanal gold processing. Although As content of soils and sediments is found to be consistently above the trigger concentrations, 
there is no significant variation between As concentration in soils and sediments in the vicinity of the mine pits and in those from background areas.

The concentrations of $\mathrm{Zr}$, Th and, to a lesser extent, $\mathrm{Ba}$ have been found to be very high in the study area (Table 2). Mean concentrations ( \pm standard deviation) of $\mathrm{Zr}$ and $\mathrm{Th}$ in the area are greater than the crustal abundances [28, 29], whereas the concentration of $\mathrm{Ba}$ is only slightly elevated above baseline concentrations. These results are broadly very similar to those obtained for stream sediments in a survey in central Nigeria [30]. The possible sources of these elements in the area is not clear, but heavy minerals like zircon and monazite are likely sources of $\mathrm{Zr}$ and $\mathrm{Th}$, while Ba may have been contributed by feldspars or associated barite mineralization.

According to Key et al. [40], anomalously high levels of $\mathrm{Zr}$ found in stream sediments in Nigeria may not be a reflection of the concentration of the element and other heavy mineral borne elements in surrounding Basement rocks. They instead interpreted it to be a product of intense tropical-chemical weathering, and persistent physical weathering aided by wet season flash floods and dry season winds, which effectively removed most of the clay minerals, thus, leaving the sediments enriched in zircon and the other resistates. The concentration of $\mathrm{Zr}$ obtained in this work for three metasedimentary rock samples ranges from 251 to 276 $\mu \mathrm{g} \mathrm{Zr} / \mathrm{g}$, similar to the results obtained for older granite samples from the Minna area in central Nigeria [40] and for schist-quartzites in SW Nigeria [31]: further supporting the argument that the high $\mathrm{Zr}$ content of soils and sediments in the area does not indicate the presence of anomalous concentrations of the element in the bedrocks. The concentrations of most of the remaining elements in the area (Table 1) are low compared to the crustal baseline values, the exception being $\mathrm{V}$ and $\mathrm{Ce}$.

\subsubsection{Enrichment Ratios}

Element enrichment ratios [41] were calculated in order to assess the extent of enrichment and /or depletion of trace elements in the soils of the two study areas relative to their crustal concentrations. In this work, the Upper Continental Crust concentrations of the elements [28] were used as baseline or background values and the enrichment ratio (ER) was calculated using the equations:

$$
E R=\frac{\boldsymbol{C n}}{\boldsymbol{B n}}
$$

where $C_{n}$ is the concentration of an element measured in a sample and $B_{n}$ is the background or baseline concentration, in this case, the upper crustal concentration of the element.

The enrichment ratios are summarized in Table 2 and show the factor by which the concentration of an element in the samples from the two areas exceeds their crustal abundances. An enrichment ratio, ER of 1 indicates that the soil or sediment is neither enriched nor depleted in a particular element relative to the average crustal concentration. On the other hand an ER of $>1$ or $<1$ is an indication of enrichment or depletion.

Table 2. Summary of enrichment ratios, ER for the samples from Birnin-Gwari area, NW Nigeria

\begin{tabular}{|c|c|c|c|}
\hline \multirow[t]{2}{*}{ Element } & \multicolumn{3}{|c|}{$\begin{array}{l}\text { Enrichment ratios, ER } \\
\qquad(\mathrm{n}=56)\end{array}$} \\
\hline & Min & Max & Mean \\
\hline $\mathrm{Sc}$ & $<0.9$ & 1.4 & 0.9 \\
\hline V & 0.4 & 1.7 & 0.96 \\
\hline $\mathrm{Cr}$ & 0.8 & 2.9 & 1.5 \\
\hline $\mathrm{Ni}$ & 0.5 & 1.5 & 0.8 \\
\hline $\mathrm{Cu}$ & $<0.4$ & 1.2 & 0.4 \\
\hline $\mathrm{Zn}$ & 0.23 & 1.1 & 0.4 \\
\hline As & 6.7 & 62.7 & 16.2 \\
\hline $\mathrm{Rb}$ & 0.3 & 1.3 & 0.7 \\
\hline $\mathrm{Sr}$ & 0.1 & 0.4 & 0.2 \\
\hline $\mathrm{Y}$ & 0.7 & 3.3 & 1.7 \\
\hline $\mathrm{Zr}$ & 1.4 & 24.5 & 9.0 \\
\hline $\mathrm{Nb}$ & 0.6 & 1.5 & 0.9 \\
\hline Mo & $<6.7$ & $<6.7$ & $<6.7$ \\
\hline $\mathrm{Ba}$ & 0.4 & 1.5 & 0.9 \\
\hline $\mathrm{La}$ & 0.8 & 2.2 & 1.3 \\
\hline $\mathrm{Ce}$ & 0.8 & 1.8 & 1.2 \\
\hline $\mathrm{Pb}$ & 1.0 & 2.6 & 1.4 \\
\hline Th & 1.1 & 4.2 & 2.0 \\
\hline $\mathrm{U}$ & $<3.6$ & $<3.6$ & $<3.6$ \\
\hline
\end{tabular}

The results show that many of the elements $(\mathrm{Sc}, \mathrm{V}, \mathrm{Ni}, \mathrm{Rb}$, $\mathrm{Sr}, \mathrm{Nb}$ and $\mathrm{Ba}$ ) are generally depleted relative to their average crustal values, with mean enrichment ratios of less than 1. The results (Table 2) show that As is the most enriched element relative to the baseline value, with an ER of about 16 . This agrees very closely with the generally higher As concentrations obtained in the top soils and stream sediments. The concentration of $\mathrm{Zr}$ is about 9 times its upper crustal concentration. Unlike the case for $\mathrm{Zr}$, the samples are only slightly enriched in Th (2 times) and $\mathrm{Pb}$ (1.4 times), while $\mathrm{Cu}$ is depleted relative to the continental crust with an ER of 0.4; further indicating that artisanal mining activities have not contaminated the environment with these elements.

\subsubsection{Index of Geoaccumulation}

One of the methods used in estimating the enrichment of the concentration of an element above the background or baseline values is to calculate the index of geoaccumulation, $I_{g e o}$, proposed by Muller [42]. This method is used to assess the severity of pollution using seven enrichment classes 
based on an increase on the numerical value of the scale (Table 3).

Table 3. Classes of the index of geoaccumulation, $I_{\text {geo }}[42]$

\begin{tabular}{|c|c|c|}
\hline$I_{\text {geo }}$ value & $I_{\text {geo }}$ class & Pollution intensity \\
\hline$>5$ & 6 & Extremely polluted \\
$4-5$ & 5 & Strongly to extremely polluted \\
$3-4$ & 4 & Strongly polluted \\
$2-3$ & 3 & Moderately to strongly polluted \\
$1-2$ & 2 & Moderately polluted \\
$0-1$ & 1 & Unpolluted to moderately polluted \\
0 & 0 & Unpolluted \\
\hline
\end{tabular}

The index of geoaccumulation, $I_{g e o}$ was calculated for all the samples according to the equations [42]:

$$
I_{g e o}=\log 2\left(\frac{C n}{1.5 B n}\right)
$$

where $C_{n}$ is the concentration of the element measured in a sample and $\mathrm{B}_{\mathrm{n}}$ is its concentration in some reference sample or background concentration, which in this case is the average crustal value $[27,28]$, while 1.5 is a constant which is introduced to minimize the effect of the variation of background values [43].

Table 4. Summary of indices of geoaccumulation, $I_{g e o}$ for trace elements in soils and sediments from Birnin-Gwari area, NW Nigeria

\begin{tabular}{|c|ccc|}
\hline \multirow{2}{*}{ Element } & \multicolumn{3}{|c|}{$\begin{array}{c}\text { Indices of geoaccumulation, } I_{\text {geo }} \\
(\mathrm{n}=56)\end{array}$} \\
\hline $\mathrm{Sc}$ & Min & Max & Mean \\
\cline { 2 - 4 } $\mathrm{V}$ & -0.7 & -0.1 & -0.7 \\
$\mathrm{Cr}$ & -1.9 & -0.2 & -0.7 \\
$\mathrm{Ni}$ & -0.9 & 0.9 & -0.1 \\
$\mathrm{Cu}$ & -1.6 & 0 & -1 \\
$\mathrm{Zn}$ & -1.9 & -0.4 & -1.8 \\
$\mathrm{As}$ & -2.7 & -0.5 & -1.9 \\
$\mathrm{Rb}$ & 2.1 & 5.4 & 3.3 \\
$\mathrm{Sr}$ & -2.4 & -0.2 & -1.2 \\
$\mathrm{Y}$ & -4.2 & -2.0 & -3.3 \\
$\mathrm{Zr}$ & -1.0 & 1.1 & 0.1 \\
$\mathrm{Nb}$ & -0.1 & 4.0 & 2.2 \\
$\mathrm{Mo}$ & -1.3 & 0.0 & -0.7 \\
$\mathrm{Ba}$ & 2.1 & 2.1 & 2.1 \\
$\mathrm{La}$ & -1.9 & 0.0 & -0.8 \\
$\mathrm{Ce}$ & -0.9 & 0.6 & -0.2 \\
$\mathrm{~Pb}$ & -0.8 & 0.3 & -0.3 \\
$\mathrm{Th}$ & -0.5 & 0.8 & -0.1 \\
$\mathrm{U}$ & -0.4 & 1.5 & 0.3 \\
& $<1.2$ & $<1.2$ & $<1.2$ \\
\hline
\end{tabular}

Table 4 is a summary of the results. Based on the $I_{g e o}$ classes in Table 3, the results of this work show that the Birnin-Gwari area may have problems relating to As contamination. The mean $I_{g e o}$ value of 3.3 for As falls within class 4 of the Muller [42] scale, indicating that the soils from this area are strongly polluted with respect to As. However, in some sample points the results correspond to class 6 or very strongly polluted, as indicated by maximum $I_{g e o}$ values $>$ 5.

However, all samples have $I_{\text {geo }}$ values below 1 for $\mathrm{Pb}$, corresponding to unpolluted to moderately polluted conditions, showing that the area has no problem with respect to $\mathrm{Pb}$ contamination of surface soils and stream sediments. The mean index of geoaccumulation for $\mathrm{Cu}$ is below 1, indicating no pollution to moderate pollution.

The results for Sc, V, Rb and Sr fall within class ' 0 ' of the scale, showing that there has not been any contamination of the soils with these elements. Similarly, the results show that the area is not polluted with respect to $\mathrm{Cr}, \mathrm{Zn}, \mathrm{Y}$ and $\mathrm{Ba}$. The soils and sediments were found to be moderately contaminated with $\mathrm{Zr}$ and $\mathrm{Th}$.

\subsubsection{Geochemical Association}

An attempt was made to hunt for geochemical associations in the study area. This was done with a view to determining the possible sources of elements, especially potentially toxic elements in the soils and sediments. Multivariate statistical methods in the form of correlation matrix $(\mathrm{CM})$ and principal component analysis (PCA) were used to classify the elements into groups that may signify common origin. All multivariate statistical tests were performed using SPSS (PASW Statistics 18) for Windows.

\subsubsection{Correlation Analysis}

Spearman correlation $\left(\mathrm{r}_{\mathrm{s}}\right)$ was used in order to assess the strength of the relationships between different elements [44], particularly as it relates to the effect of artisanal mining activities. This non-parametric correlation method was chosen in order to avoid problems associated with non-normally distributed data [45]. The Spearman correlation coefficient, $r_{s}$, is significant in all cases at 0.01 level of significance.

An interesting feature of the data is the very strong correlation observed between the lithophile elements $\mathrm{Y}, \mathrm{Nb}$, $\mathrm{Th}, \mathrm{TiO}_{2}, \mathrm{Zr}, \mathrm{Ce}$ and $\mathrm{La}$, with the correlation coefficient between $\mathrm{Y}$ and the other elements ranging from 0.51 to 0.92 $(p=0.01)$. When compared with each other, the relationships were also found to be very strong, with the correlation coefficients of $\mathrm{Nb} / \mathrm{Th}, \mathrm{TiO}_{2} / \mathrm{Zr}, \mathrm{Nb} / \mathrm{TiO}_{2}$ and $\mathrm{La} / \mathrm{Ce}$ being $0.91,0.81,0.89$ and 0.83 respectively. The close association of these elements in the samples may be an indication of the effect of resistant heavy minerals from felsic rocks (mainly granites and gneisses) on the geochemistry of soils and sediments in the area.

Similarly, there is a strong positive correlation between iron oxide and manganese oxide in the study area $\left(\mathrm{r}_{\mathrm{s}}=0.76, \mathrm{p}\right.$ $=0.01$ ) and between each of the oxides and $\mathrm{Sc}, \mathrm{V}, \mathrm{Cr}, \mathrm{Ni}, \mathrm{Cu}$, $\mathrm{Zn}$ and to a lesser extent, Sr. This shows the importance of $\mathrm{Fe} / \mathrm{Mn}$ oxides in controlling the geochemistry of trace elements in soils and sediments [30], although the correlation appears to be stronger between iron oxide and the 
trace elements than between them and manganese oxide. These relationships, as well as those between the trace elements and magnesium oxide are similar to the loadings of component 1 of the principal component factor analysis in this study.

The results do not show any particularly strong correlation between As and any other element, probably indicating a different source. The highest coefficients of correlation obtained is 0.41 for $\mathrm{As} / \mathrm{TiO} 2$. Considering that the concentration of As in samples from the area have been consistently higher than those of majority of the other trace elements, the seeming lack of association with other elements, including the major oxides is probably an indication of a different origin or source for the metalloid in the soils and sediments of the area. It is speculated that a possible source of As in these soils and sediments is the use of pesticides in farmlands.

\subsubsection{Principal Component Analysis}

Based on the high concentrations of some elements obtained in certain sampling sites and the strong correlation between the elements indicated by the Spearman correlation matrix, the data was treated using principal component analysis, in order to further assess the relationship patterns. Varimax orthogonal rotation with Kaiser Normalization was applied to the PCA in order to minimize the effects of non-normal data [44], especially the effects of high concentrations, and components were extracted based on Kaiser's default Eigenvalue of 1 [45].

Five components (Table 5), explaining about $84 \%$ of the variance were extracted. Component 1 is associated with the loadings of $\mathrm{P}_{2} \mathrm{O}_{5}, \mathrm{CaO}, \mathrm{MgO}, \mathrm{Fe}_{2} \mathrm{O}_{3}, \mathrm{MnO}$, along with $\mathrm{Zn}$ and $\mathrm{Ni}$, while component 2 is strongly positively correlated with $\mathrm{Y}, \mathrm{Nb}, \mathrm{Th}, \mathrm{TiO}_{2}, \mathrm{Zr}$, La and $\mathrm{Ce}$. The third component is associated mainly with $\mathrm{Sc}, \mathrm{Al}_{2} \mathrm{O}_{3}, \mathrm{~V}, \mathrm{Cr}, \mathrm{Cu}$, along with less strong correlation with $\mathrm{Ni}, \mathrm{Rb}$ and $\mathrm{K}_{2} \mathrm{O}$. The last two components have $\mathrm{Sr}, \mathrm{Ba}, \mathrm{Pb}, \mathrm{K}_{2} \mathrm{O}$ and $\mathrm{As}, \mathrm{Na}_{2} \mathrm{O}$ and $\mathrm{Rb}$ respectively.

Principal component analysis does not show with certainly what controls the distribution of elements in environmental matrices, but useful inferences may be drawn from the data. Component 1 has the association of $\mathrm{P}_{2} \mathrm{O}_{5}$, $\mathrm{Fe}_{2} \mathrm{O}_{3}, \mathrm{MnO}, \mathrm{Zn}, \mathrm{Ni}, \mathrm{MgO}$ and $\mathrm{CaO}$ and to some extent, $\mathrm{La}$ and $\mathrm{V}$. The correlation of these elements in the component (Table 6) may be an indication of geogenic influence, probably the acidic igneous rocks and their metamorphic products [46]. The association of the lithophile elements $\mathrm{Y}$, $\mathrm{Nb}, \mathrm{Th}, \mathrm{Ti}, \mathrm{Zr}, \mathrm{Ce}$ and $\mathrm{La}$ in component 2 (Table 6) has already been observed from the correlation matrix and is again interpreted as an indication of the influence of the granitic rocks [46] and heavy mineral grains concentrated by placer processes on the chemistry of soils and sediments in the area. The strong positive correlation between component 4 and $\mathrm{Sr}, \mathrm{Ba}, \mathrm{Pb}$ and $\mathrm{K}_{2} \mathrm{O}$ is similar to the pattern in the correlation matrix for the area and may indicate that the distribution of these elements in the soils and sediments of the area is controlled by clay minerals and mica [30]. This further strengthens the view that $\mathrm{Pb}$ in these samples may not be related to the artisanal mining, but is contributed by lithogenic sources, such as the weathering of mica.

Table 5. Total variance explained for element contents in soils and stream sediments

\begin{tabular}{|c|c|c|c|c|c|c|c|c|c|c|c|}
\hline \multirow[t]{2}{*}{ from Birnin-Gwari areas of NW Nigeria. } & \multirow{2}{*}{ Comp } & \multicolumn{4}{|c|}{$\underline{\text { Initial Eigenvalue }}$} & \multicolumn{3}{|c|}{$\begin{array}{l}\text { Extraction Sums of } \\
\text { Squared Loadings }\end{array}$} & \multicolumn{3}{|c|}{$\begin{array}{c}\text { Rotation Sums of Squared } \\
\text { Loadings }\end{array}$} \\
\hline & & Total & $\begin{array}{l}\% \\
\text { Var }\end{array}$ & Cumul & $\%$ & Total & $\begin{array}{c}\% \\
\text { Var }\end{array}$ & Cumul \% & Total & $\begin{array}{c}\% \\
\text { Var }\end{array}$ & Cumul $\%$ \\
\hline & 1 & 9.6 & 34.4 & 34.4 & & 9.6 & 34.4 & 34.4 & 6.6 & 23.5 & 23.5 \\
\hline & 2 & 5.7 & 20.4 & 54.8 & & 5.7 & 20.4 & 54.8 & 5.7 & 20.2 & 43.7 \\
\hline & 3 & 3.8 & 13.5 & 68.3 & & 3.8 & 13.5 & 68.3 & 5.2 & 18.5 & 62.2 \\
\hline & 4 & 2.7 & 9.7 & 78.0 & & 2.7 & 9.7 & 78.0 & 3.2 & 11.5 & 73.6 \\
\hline & 5 & 1.6 & 5.7 & 83.7 & & 1.6 & 5.7 & 83.7 & 2.8 & 10.1 & 83.7 \\
\hline & 6 & 0.9 & 3.2 & 86.9 & & & & & & & \\
\hline
\end{tabular}


Table 6. Rotated component matrix for elements contents in soils and stream sediments from Birnin-Gwari area, NW Nigeria

\begin{tabular}{|c|c|c|c|c|c|}
\hline \multirow{2}{*}{ Element } & \multicolumn{5}{|c|}{ Component } \\
\hline & 1 & 2 & 3 & 4 & 5 \\
\hline $\mathrm{P}_{2} \mathrm{O}_{5}$ & 0.93 & & & & \\
\hline $\mathrm{FeO}_{3}$ & 0.93 & & & & \\
\hline $\mathrm{MnO}$ & 0.91 & & & & \\
\hline $\mathrm{Zn}$ & 0.8 & & & & \\
\hline LOI & 0.79 & & & & \\
\hline $\mathrm{Ni}$ & 0.78 & & & & \\
\hline $\mathrm{SiO}_{2}$ & -0.72 & & & & \\
\hline $\mathrm{MgO}$ & 0.54 & & & & \\
\hline $\mathrm{CaO}$ & 0.54 & & & & \\
\hline $\mathrm{Y}$ & & 0.95 & & & \\
\hline $\mathrm{Nb}$ & & 0.94 & & & \\
\hline $\mathrm{Th}$ & & 0.93 & & & \\
\hline $\mathrm{TiO}_{2}$ & & 0.91 & & & \\
\hline $\mathrm{Zr}$ & & 0.84 & & & \\
\hline $\mathrm{Ce}$ & & 0.81 & & & \\
\hline $\mathrm{La}$ & & 0.66 & & & \\
\hline $\mathrm{Sc}$ & & & 0.91 & & \\
\hline $\mathrm{Al}_{2} \mathrm{O}_{3}$ & & & 0.81 & & \\
\hline $\mathrm{V}$ & & & 0.81 & & \\
\hline $\mathrm{Cr}$ & & & 0.74 & & \\
\hline $\mathrm{Cu}$ & & & 0.65 & & \\
\hline $\mathrm{Sr}$ & & & & 0.90 & \\
\hline $\mathrm{Ba}$ & & & & 0.82 & \\
\hline $\mathrm{Pb}$ & & & & 0.75 & \\
\hline $\mathrm{K}_{2} \mathrm{O}$ & & & & 0.56 & \\
\hline As & & & & & 0.83 \\
\hline $\mathrm{Na}_{2} \mathrm{O}$ & & & & & 0.72 \\
\hline $\mathrm{Rb}$ & & & & & 0.63 \\
\hline
\end{tabular}

\section{Conclusion}

The results that surface soils and sediments from the Tsofon Birnin-Gwari area are depleted in base cations and alumina, but enriched in silica, relative to the upper continental crust, consistent with the findings of other workers in Nigeria. This is attributed to intensive tropical chemical weathering, coupled with physical removal of fine clay minerals through the combined effect of wet season overland runoff and dry season winds on the one hand, and the movement of base cations into deeper horizons of soils through leaching. This may have implications for surface water quality by lowering of $\mathrm{pH}$ due to reduced capacity of soils to supply alkalis and the mobility of contaminant trace elements. The same mechanism is identified as the reason for the high concentration of $\mathrm{Zr}$ found in soils and sediments in the area; the bedrocks were found not to have high concentrations of zirconium. The main concern identified in the Birnin-Gwari area is the comparatively high As concentrations in soils and sediments, which does not appear to be controlled by the artisanal gold mining activities.

\section{Acknowledgements}

This work is part of the thesis submitted to the School of Environmental Sciences, University of East Anglia, UK in candidature for the degree of doctor of philosophy. I am grateful to the Petroleum Technology Development Fund (PTDF), an arm of the Federal Government of Nigeria for funding it under the Overseas Scholarship Scheme.

\section{REFERENCES}


[1] Kelly, M. (1988). Mining and the fresh water environment. Elsevier Science Publishers, London. p.231.

[2] Thornton, I. (1996). Impacts of mining on the environment; some local, regional and global issues. Appl Geochem 11, 355-361.

[3] Dudka, S., Adriano, D.C. (1997). Environmental impacts of metal mining and processing: A review. Journ. Environ. Qual. 26(3), 590-602.

[4] Lottermoser, B.G. (2007). Mining environments: the good, the bad and the ugly. Paper presented at the Mining and Environment IV Conference, Sudbury, Ontario,Canada, October, 2007.

[5] Plumlee, G.S., Morman, S.A. (2011). Mine wastes and human health. Elements 7 (6), 399-404.

[6] Hilson, G. (2002). The environmental impact of small-scale mining in Ghana: identifying problems and possible solutions. The Geogr. Jour. 168 (1), 57-72.

[7] Babut, M., Sekyi, R., Rambaud, A., Potin Gautier, M., Tellier, S., Bannerman, W et al. (2003). Improving the environmental management of small-scale gold mining in Ghana: a case study of Dumasi. Journ. Cleaner Prod 11, 215-221.

[8] Appleton, J.D., Williams, T.M., Orbea, H., Carrasco, M. (2001). Fluvial contamination associated with artisanal gold mining in the Ponce Enriquez, Portovelo-Zaruma and Nambija areas, Ecuador. Water Air Soil Poll 131, 19-39.

[9] Hinton, J.H., Veiga, M.M., Tadeu, A., Veiga, C. (2003). Clean artisanal gold mining: a utopian approach? Jour. Cleaner Prod. 11, 99-115.

[10] Jung, M.C. (2001). Heavy metal contamination of soils and waters in and around the Imcheon $\mathrm{Au}-\mathrm{Ag}$ mine, Korea. Appl Geochem 16, 1369-1375.

[11] Federal Surveys of Nigeria. (1967).Quarter degree topographic maps of Kwaimbana SE (sheet 100SE) and Kushaka NE (sheet 122NE).

[12] Turner, D.C. (1983). Upper Proterozoic schist belts in the Nigerian sector of the Pan African province of West Africa. Precambrian Res. 21, 55-79.

[13] Truswell, J.F. and Cope, R.N. (1963). The geology of parts of Niger and Zaria Provinces, northern Nigeria. Bull. Geol. Surv. Nigeria 29, 53pp.

[14] Garba, I. (2000). Gold prospects of the Nigerian Pan-African terrain of West Africa. J. Min. Geol. 36(2), 123-136.

[15] Woakes, M., Bafor, B.E. (1983). Primary gold mineralization in Nigeria. In R.P. Foster, Ed GOLD '82: The Geology, Geochemistry and Genesis of gold deposits. Geol Soc Zimbabwe Spec Publication no.1. Balkema, Rotterdam.

[16] Garba, I. (2002). Geochemical Characteristics of the Gold Mineralization near Tsohon Birnin-Gwari, north-western Nigeria. Chem. Erde 62, 160-170.

[17] Russ, W. (1957). The geology of parts of Niger, Zaria and Sokoto Provinces. Geological Survey of Nigeria Bulletin no. 27, pp. 35

[18] Garba, I. (2003). Geochemical characteristics of mesothermal gold mineralization in the Pan-African $(600 \pm 150 \mathrm{Ma})$ basement of Nigeria. Trans. Inst. Min. Metall. 112, 319-325.
[19] Waziri, N.M. (2012). Environmental Geochemistry of Soils and Stream Sediments from the Anka and Birnin-Gwari Artisanal Gold Mining areas, NW Nigeria. Unpublished PhD Thesis, University of East Anglia UK.

[20] Potts, J.P., Webb, P.C. (1992). X-ray fluorescence spectrometry. J.Geochem. Explor. 44, 251-296.

[21] Funtua, I.I. (2001). Elemental composition of Sn-Nb-Ta mine tailings of Jos area, Central Nigeria. Chem. Erde. 61, 45-53.

[22] Bruker Advanced X-rays Solutions. (2004). Introduction to $\mathrm{X}$-ray fluorescence analysis (XRF). User's manual.

[23] Nehls, G.J., Akland, G.G. (1973). Procedures for handling aerometric data. J. Air Pollut. Control Ass. 23, 180-184.

[24] Kushner, E.J. (1976). On determining the statistical parameters for pollution concentration from a truncated data set. Atmosph. Environ. 10, 975-979.

[25] USEPA. (2000). Assigning values to non-detected/ non-quantified pesticide residue in human food exposure assessments. Office of Pesticide Programs. [Online] http://www.epa.gov/oppfead1/trac/science/trac3b012.pdf [15/11/2012]

[26] Andrews, J.E., Brimblecombe, P., Jickells, T.D., Liss, P.S., Reid, B (2004). An introduction to environmental chemistry. 2nd edition, Blackwell Publishing, Oxford.

[27] Taylor, S.R., McLennan, S.M. (1985). The Continental Crust: its Composition and Evolution. Blackwell Scientific Publication, Oxford.

[28] Taylor, S.R., McLennan, S.M. (1995). The geochemical evolution of continental crust. Rev Geophysics 33(2), 241-265.

[29] Wedepohl, K.H. (1995). The composition of the continental crust. Geochim Cosmochim Acta 59 (7), 1217-1232.

[30] Lapworth, D.J., Knights, K.V., Key, R.M., Johnson, C.C., Ayoade, E., Adekanmi, M.A. et al. (2012). Geochemical mapping using stream sediments in west-central Nigeria: Implications for environmental studies and mineral exploration in West Africa. Appl. Geochem. 27, 1035-1052.

[31] Tijani, M.N., Okunlola, O.A., Abimbola, A.F. (2006). Lithogenic concentrations of trace metals in soils and saprolites over crystalline basement rocks: a case study from SW Nigeria. J. Afr. Earth Sci. 46, 427-438.

[32] Price, J.R., Velbel, M.A. (2003). Chemical weathering indices applied to weathering profiles developed on heterogeneous felsic metamorphic rocks. Chem Geol 202, 397-416.

[33] Nesbitt, H.W., Young, G.M. (1982). Early Proterozoic climates and plate motions inferred from major element chemistry of lutites. Nature 299, 715-717.

[34] Pullan, R.A. (1970). The soils, soil landscapes and geomorphological evolution of a metasedimentary area in northern Nigeria. Research Paper No 6, Department of Geography, University of Liverpool, UK, p.144.

[35] Kirchner, J.W. (1992). Heterogeneous geochemistry of catchment acidification. Geochim Cosmochim Acta 56, 2311-2327.

[36] Kirchner, J.W. (1995). Base cation depletion and potential 
long-term acidification of Norwegian catchments. Environ Science Tech 29 (8), 1953-1960.

[37] Sako, A., Mills, A.J., Roychoudhry, A.N. (2009). Rare earth and trace element geochemistry of termite mounds in central and northeastern Namibia: Mechanisms for micro-nutrient accumulation. Geoderma 153, 217-230.

[38] Inam, E., Khantotong, S., Kim, K., Tumendemberel, B., Erdenetsetseg, S., Puntsag, T. (2011). Geochemical distribution of trace element concentrations in the vicinity of Boroo gold mine, Selenge Province, Mongolia. Environ Geochem Health 33, 57-69.

[39] Carvalho, P.C.S., Neiva, A.M.R., Silva, M.M.V.G. (2009). Geochemistry of s stream sediments and waters close to abandoned $\mathrm{W}-\mathrm{Au}-\mathrm{Sb}$ mines at Sarzedas, Castelo Branco, central Portugal. Geochem: Explor Environ Anal 9, 341-352.

[40] Key, R.M., Johnson, C.C., Horstwood, M.S.A., Lapworth, D.J., Knights, K.V., Kemp, S.J. et al. (2012). Investigating high zircon concentrations in the fine fraction of stream sediments draining the Pan-African Dahomeyan Terrane in Nigeria. Appl Geochem 27(8), 1525-1539.
[41] Albright, E.I. (2004). Background concentrations of trace elements in soils and rocks of the Georgia Piedmont. M.Sc. thesis, The University of Georgia.

[42] Muller, G. (1969). Index of geoaccumulation in sediments of the Rhine River. Geojournal 2, 108-118.

[43] Abrahim, G.M.S., Parker, R.J. (2008). Assessment of heavy metal enrichment factors and the degree of contamination in marine sediments from Tamaki Estuary, Auckland, New Zealand. Environ Monit Assess 136, 227-238.

[44] Gong, M., Wu, L., Bi, X., Ren, L., Wang, L., Ma, Z. et al. (2010). Assessing heavy metal contamination and sources by GIS based approach and multivariate analysis of urban-rural top soils in Wuhan, central China. Environ Geochem Health $32,59-72$.

[45] Field, A. (2009). Discovering statistics using SPSS, 3rd edition, SAGE London.

[46] Zibret, G., Sajn, R. (2010). Hunting for geochemical associations of elements: factor analysis and self-organizing maps. Math Geosci 42, 681-703. 